\title{
Ethylnitrosourea Induces Neoplasia in Zebrafish (Danio rerio)
}

\author{
Lee G. Beckwith, Jessica L. Moore, Gladys S. Tsao-Wu, John C. Harshbarger, and \\ Keith C. Cheng
}

Jake Gittlen Cancer Research Institute, Department of Pathology (LGB, JLM, KCC), Department of Surgery (GST-W), and Department of Biochemistry and Molecular Biology (KCC), Pennsylvania State University College of Medicine, Hershey, Pennsylvania; and Registry of Tumors in Lower Animals, Department of Pathology (JCH), George Washington University Medical Center, Washington, D.C.

SUMMARY: The zebrafish (Danio rerio) has been successfully used to discover hundreds of genes involved in development and organogenesis. To address the potential of zebrafish as a cancer model, it is important to determine the susceptibility of zebrafish to tumors. Germ line mutations are most commonly induced for zebrafish mutant screens by exposing adult male zebrafish to the alkylating agent, ethylnitrosourea (ENU). To determine whether ENU induces tumors, we compared the incidence of tumors in ENU-treated fish with untreated controls. Interestingly, 18 of $18(100 \%)$ fish mutagenized with either 2.5 or 3.0 mm ENU developed epidermal papillomas, which numbered 1 to 22 per fish, within 1 year of treatment. The induced epidermal lesions included epidermal hyperplasia, flat papillomas $(0.2$ to $1.2 \mathrm{~mm}$ ), and pedunculated papillomas ( 1.2 to $8 \mathrm{~mm}$ in greatest dimension), but no skin cancers. Angiogenesis was evident in papillomas larger than approximately $1 \mathrm{~mm}$. All but two papillomas contained the three cell types (keratinocytes, club, and mucous cells) of normal zebrafish epidermis; histologic variants lacked either club cells or mucous cells. Two cavernous hemangiomas and a single malignant peripheral nerve sheath tumor were also found in the treated fish. None of five untreated controls developed tumors. These studies establish the feasibility of the zebrafish as an experimental model for the study of skin tumors. (Lab Invest 2000, 80:379-385).

$T$ he zebrafish (Danio rerio), also known as zebra danio (Robins et al, 1991), was introduced as a model for carcinogen studies at the National Cancer Institute by Mearl Stanton (1965). More recently, the zebrafish has also become an important model system for the study of biological problems relating to human disease, including development and organogenesis (Driever and Fishman, 1996; Eisen, 1996; Zon, 1999). To address the feasibility of the zebrafish as a cancer model, it is useful to establish the sensitivity of zebrafish to chemical carcinogens. Ethylnitrosourea (ENU) is a direct-acting alkylating agent (reviewed by Shibuya and Morimoto, 1993) that is well known to cause tumors in a variety of animal models including the Eker rat (Kobayashi et al, 1997), the SpragueDawley rat (Koestner et al, 1971), and Xiphophorus (platyfish/swordtail fish) (Schartl et al, 1997). We therefore reasoned that tumors may arise in males exposed to ENU in a commonly-used germ line mutagenesis protocol (Mullins et al, 1994; Solnica-Krezel et al,

Received November 2, 1999.

Supported by National Institutes of Health Grants 5R01-CA73935 (KCC), $1 F 32$ GM19794 (JLM), and NO1-CB-77021 (JCH); National Science Foundation Grant MCB-9604923 (KCC); and Jake Gittlen Memorial Golf Tournament.

Address reprint requests to: Dr. K. C. Cheng, Jake Gittlen Cancer Research Institute, H059, Pennsylvania State University College of Medicine, 500 University Drive, Hershey, Pennsylvania 17033. Fax: (717) 531-5634; E-mail:kcheng@psu.edu
1994). Here, we report that, within 1 year of treatment, ENU induced an unexpectedly high frequency of papillomas in adult male zebrafish.

\section{Results and Discussion}

To prepare for two mutant screens in our laboratory (J. Moore, G. Tsao-Wu, and K. Cheng, unpublished observations), adult male zebrafish were treated with three 1-hour immersions in 2.5 or $3 \mathrm{~mm}$ ENU every third day (Mullins et al, 1994). The frequency of ENUinduced germ line mutations was measured by crossing the treated males by untreated females homozygous for golden. This recessive mutation causes a delayed and decreased pigmentation in retinal pigmented epithelium and melanocytes (Streisinger et al, 1986). We used golden as a marker, because ENUinduced mutations in golden occur at a rate between that of two other marker genes, albino and sparse (Solnica-Krezel et al, 1994). The mutation rates caused by $0,2.5$, and $3.0 \mathrm{~mm}$ ENU treatments were $0 \%(0$ golden embryos of 1460 embryos scored), $0.11 \%$ (2 golden embryos of 1818), and $0.26 \%$ (5 golden embryos of 1905), respectively. These rates are approximately double that reported by other laboratories (Mullins et al, 1994; Solnica-Krezel et al, 1994). The difference may be potentially attributed to lot-to-lot variability of ENU or the shorter time elapsed between the beginning of the ENU dissolution procedure and dosing in our experiments (1 hour maximum). 
Ten to twelve months after exposure, all 18 (100\%) of the ENU-treated adult male fish (Fish F-W) developed epidermal papillomas; two also developed other tumors (Figs. 1 to 3). None of five control fish (Fish A to E) developed tumors of any type. The average number of papillomas per fish was 2 to 3 (range 1 to 7 ) for the $2.5 \mathrm{~mm}$ ENU-treated group (Fish F to M) $(n=8)$, and 6 (range 1 to 22) for the $3.0 \mathrm{~mm}$ group (Fish $\mathrm{N}$ to $\mathrm{W}$ ) ( $n=$ 10) (Fig. 3). These data suggest that the number of papillomas per fish may be dose-dependent. The
$100 \%$ incidence of papillomas in ENU-treated fish and absence of papillomas in controls indicate that ENU induced the papillomas.

Grossly, all but two papillomas were white, smooth, and glistening (Fig. 1, A and D). Microscopically, these papillomas were composed of a mixture of the three cell types of normal zebrafish epidermis: keratinocytes, and club and mucous cells. Club cells (Schreckstoffzellen, alarm substance cells) measure 15 to 20 $\mathrm{mm}$, have pink cytoplasm that is frequently scalloped
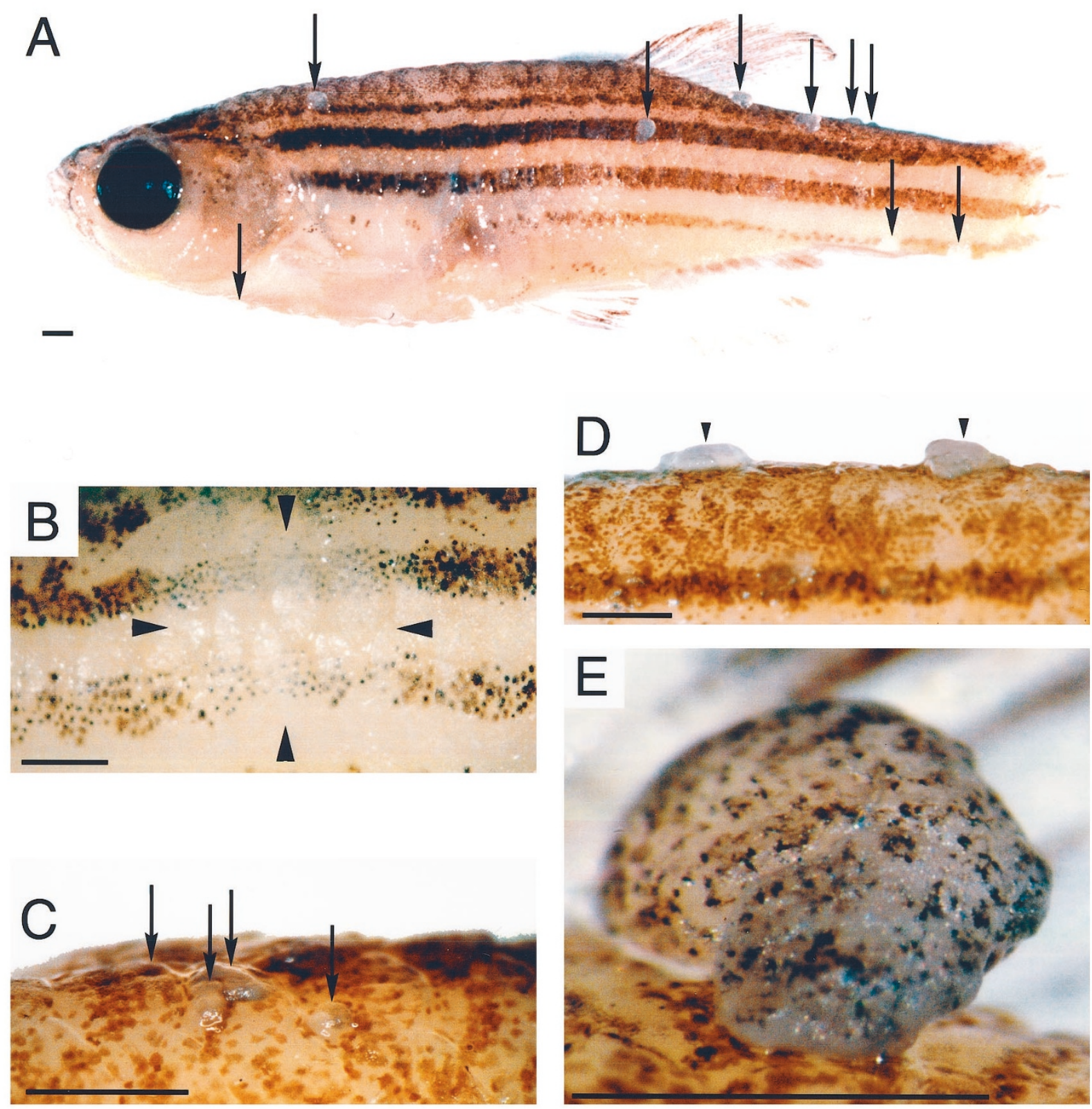

\section{Figure 1.}

Ethylnitrosourea (ENU)-induced hyperplasia and papillomas (gross). A, Multiple papillomas (arrows) in a fish with a total of 22 papillomas (Fish W). B, This white plaque of epidermal hyperplasia (between arrowheads) obscured the normal melanophore pattern of the zebrafish stripes (brown dot pattern, left and right) (Fish K). Epidermal hyperplasia obscured the pigment pattern, because melanophores are near the epidermal basement membrane, deep to the thickened epidermis. C, Early sessile papillomas (arrows) frequently occurred at or near the distal ends of scales (Fish I). D, Two sessile papillomas (arrowheads) on the dorsum, midline, of Fish O. E, A pigmemted pedunculated papilloma. This papilloma was $1.5 \times 1.2 \times 1 \mathrm{~mm}$ and had a narrower $0.4 \times 0.3 \times 0.1 \mathrm{~mm}$ stalk (Fish N). Cells with melanin pigment were present histologically (see Fig. 2F). Scale bars: $1 \mathrm{~mm}$. 

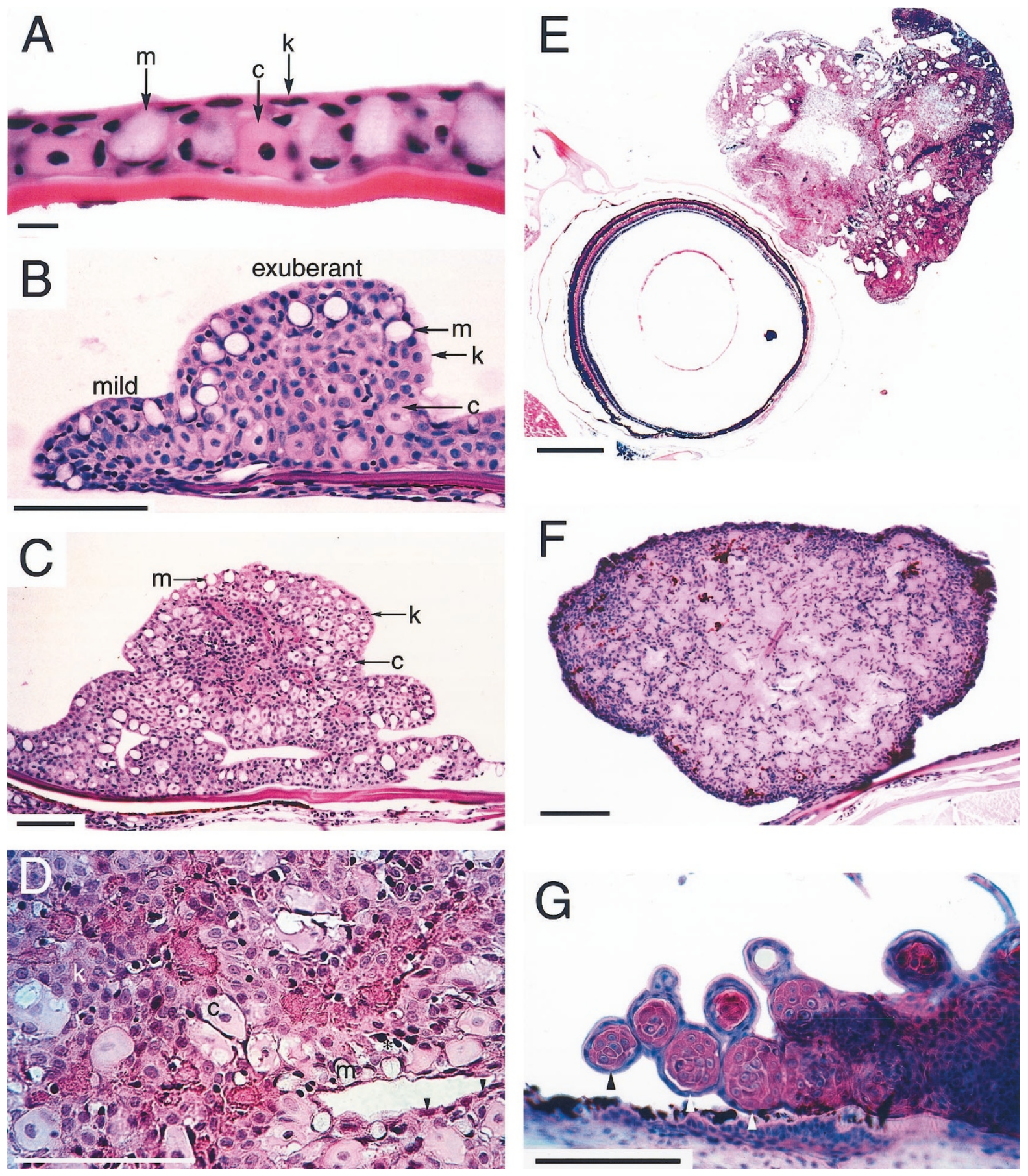

\section{Figure 2.}

Microscopic appearance of epidermal lesions induced by ENU. A, Normal epidermis of body scales is thin and is composed of keratinocytes $(k)$, mucous cells $(m)$, and club cells $(c)$. Keratinocytes $(k)$ are squamous epithelial cells that are red, slightly smaller than club cells, and that have intercellular desmosomes. Mucous cell nuclei are pushed to one side. Mucous cells stain light blue with hematoxylin and eosin after formaldehyde fixation (shown), and deep blue after paraformaldehyde fixation (not shown). Club cells are pink, with central nuclei and occasionally scalloped edges. Scale bar:10 mm. B, Hyperplastic epidermis was thicker than normal but was composed of the same cell types as normal epidermis. Scale bar: $100 \mathrm{~mm}$. C, Sessile (broad-based) papilloma composed of keratinocytes ( $k$ ), mucous cells $(m)$, and club cells $(c)$. Scale bar: $100 \mathrm{~mm}$. D, Pedunculated papilloma. All except two pedunculated papillomas were composed of keratinocytes $(k)$, mucous cells $(m)$, and club cells $(c)$. Medium-sized vascular spaces were lined by a thin endothelium (arrowheads). Capillaries ${ }^{*}$ ) contained red blood cells which have dark nuclei and red cytoplasm. Scale bar: $100 \mathrm{~mm}$. E, Pedunculated papilloma. This is a section of the largest papilloma, which measured $8 \times 4 \times 4 \mathrm{~mm}$, and was attached to the dorsal surface of the head between the eyes of fish $\mathrm{H}$ by a $0.3 \times 0.3 \times 0.1 \mathrm{~mm}$ stalk. The papilloma and eye are shown; the remainder of the body extends to the left. Histologically, keratinocytes and mucous cells, but not club cells, were arranged in solid, nested, papillary, or glandular patterns. Vascular spaces were present. Scale bar: $1 \mathrm{~mm}$. F, Pigmented papilloma. This papilloma variant was composed predominantly of a uniform population of keratinocytes that flatten towards the surface and that are arranged in cords around circular areas of dense collagen and basement membrane material. Numerous melanophores account for the dark brown spotted pattern seen grossly (see Fig. 1E). Scale bar: $100 \mathrm{~mm}$. G. Whorls of squamous cells (squamous eddies, arrowheads), occurred at the distal end of spiny rays of some fins. Scale bar: $100 \mathrm{~mm}$. Hematoxylin and eosin. 


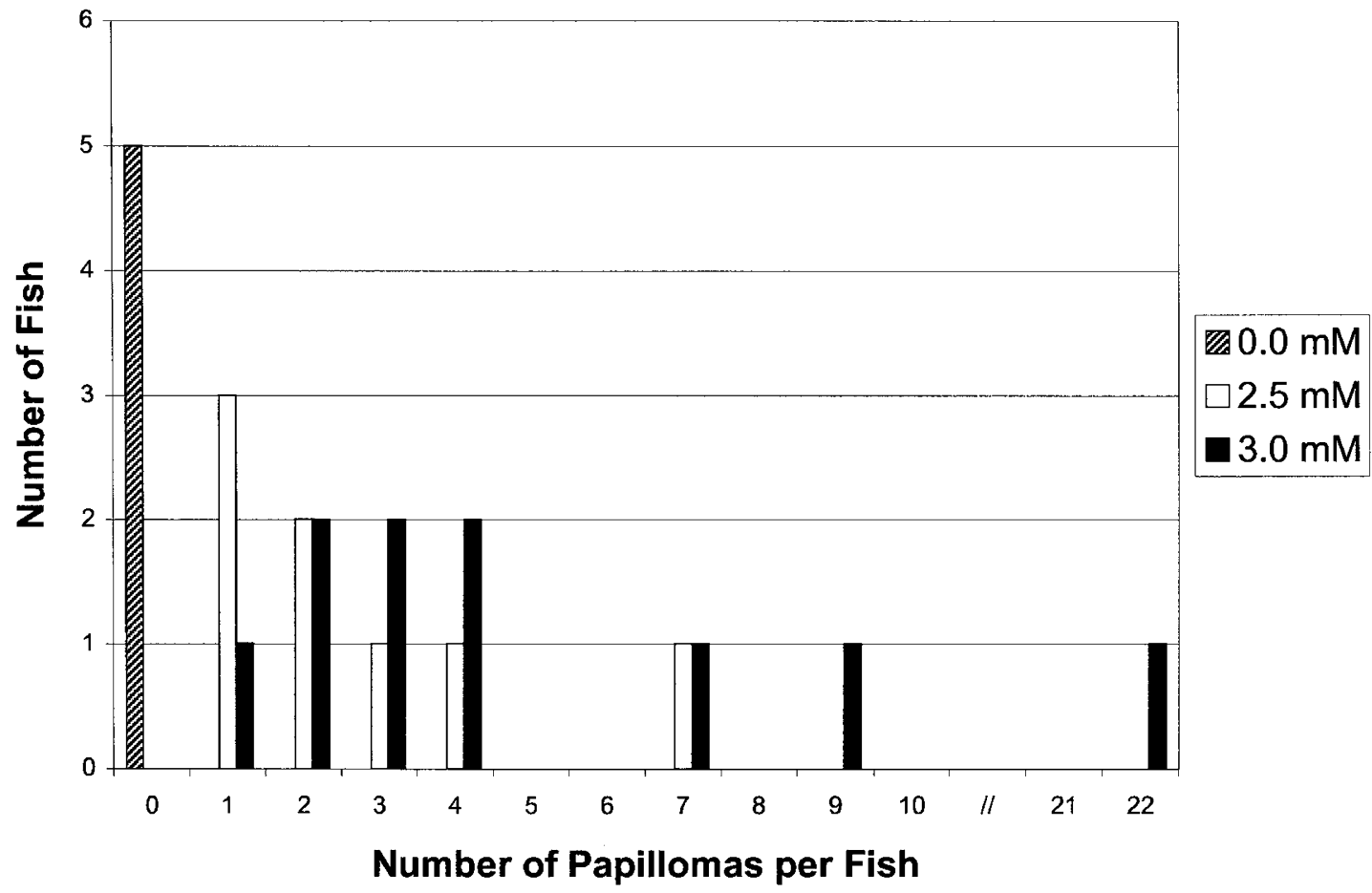

Figure 3.

Number of papillomas per fish. A greater number of papillomas tended to be associated with fish dosed with ENU at $3.0 \mathrm{~mm}$ compared with those dosed at $2.5 \mathrm{~mm}$. None of five control $(0.0 \mathrm{~mm})$ fish developed tumors.

at the edges (Fig. 2D), and have central nuclei. In addition to these three cell types, two papillomas, on Fish $\mathrm{S}$ and V, also contained few scattered melanophores (melanocytes) (not shown). The histologic range of induced epidermal lesions included epidermal hyperplasia (Figs. 1B and $2 \mathrm{~B}$ ), flat papillomas (0.2 to $1.2 \mathrm{~mm}$ ) (Figs. 1, A, C, and D; and 2, B and C), and pedunculated papillomas (1.2 to $8 \mathrm{~mm}$ in greatest dimension) (Figs. 1E, and 2, D to F). None of the papillomas were invasive.

Two papillomas were histologically different. One of these, the largest papilloma, was an $8 \times 4 \times 4 \mathrm{~mm}$ pale, pink, fleshy, pedunculated mass on the dorsal head between the eyes of Fish H (Fig. 2E). Microscopically, it was composed primarily of keratinocytes admixed with a small number of mucous cells. Club cells were absent (not shown). The second papilloma variant occurred near the dorsal fin in Fish N (Fig. 1E). Grossly, this papilloma was $1.5 \times 1.2 \times 1 \mathrm{~mm}$, and pedunculated. Microscopically, the keratinocytes in this lesion were basaloid, and arranged in trabecular and cylindromatous patterns. In contrast to the other lesions, club cells were few, mucous cells were absent, and numerous scattered melanophores (melanocytes) accounted for the grossly pigmented pattern (Figs. 1E and 2F). The absence of either club cells or mucous cells in these variants makes the keratinocyte the only consistent cell type in these papillomas.

Progression from non-dysplastic papillomas to dysplastic papillomas to malignant skin tumors has been studied in the mouse (Berenblum, 1954; Berenblum and Shubik, 1949; Boutwell, 1964; DiGiovanni, 1992; Friedewald and Rous, 1944; Yuspa, 1998). In SENCAR mouse skin, ENU functions as a tumor initiator at lower doses, but as a complete carcinogen at higher doses (O'Connell et al, 1987). It is unknown whether ENU-induced papillomas in zebrafish would progress to carcinomas by the use of higher or more frequent doses of ENU, tumor promoters, or DNA alkyl adduct repair enzyme inhibitors, such as the $O^{6}$-alkylguanine transferase inhibitor, $O^{6}$-benzylguanine (Lijinsky et al, 1994; Tong et al, 1997).

ENU-induced zebrafish skin papillomas described here differ histologically from carcinogen-induced mouse skin papillomas. First, mouse papillomas consist of keratinocytes (Bogovski, 1994; Peckham and Heider, 1999); whereas, the zebrafish papillomas often also contain mucous and club cells (Fig. 2, B to D). Second, mouse papillomas exhibit hyperkeratosis (Bogovski, 1994; Peckham and Heider, 1999), which is absent in the zebrafish papillomas. Third, the stroma of mouse papillomas is fibrovascular and exhibits papillomatosis (Bogovski, 1994; Peckham and Heider, 1999); whereas, the stroma of the zebrafish papillomas consists of a more delicate vasculature (Fig. 2D).

We found a $100 \%$ incidence of skin tumors after three 1-hour treatments within a 1 week period. A $100 \%$ incidence of skin tumors was also reported in the SENCAR mouse after a minimum of 27 weekly doses of ENU to shaved skin (O'Connell et al, 1987). It is noteworthy that the three ENU doses here induced no carcinomas in zebrafish. However, a minimum of 15 weekly topical treatments with ENU were required to induce skin carcinomas in mice (O'Connell et al, 1987). It is also interesting that ENU induced such a high incidence of skin tumors in zebrafish without 
detectable tumors in other organs of high cell turnover, such as gut or testis. The difference in tumor induction between skin and internal organs may be due to either a lower tissue concentration secondary to systemic absorption, or less efficient repair of DNA alkylation damage in skin (Tong et al, 1997).

Angiogenesis was evident in papillomas larger than $1 \mathrm{~mm}$ (Fig. 2D). Angiogenesis has been described in benign papillomas induced with 7,12dimethylbenz[a]anthracene (tumor initiator) and 12-Otetradecanoylphorbol-13-acetate (tumor promoter) in mice (Bolontrade et al, 1998).

Raised papillomas of the skin have not, to the best of our knowledge, been reported previously in the zebrafish. The most similar reported zebrafish epidermal tumor is an inverted squamous papilloma that involved the dermis in a zebrafish exposed as an embryo to 3000 parts per million N-nitrosodiethyl-amine (Tsai, 1996). Zebrafish tumors other than papillomas have been induced by $\mathrm{N}$-nitrosodiethylamine, aflatoxin $\mathrm{B} 1$, methylazoxymethanol acetate, N-methyl-N'-nitro-Nnitrosoguanidine, or 7,12-dimethylbenz[a]anthracene through solution exposure or feed, but never at a 100\% frequency (Hendricks, 1996; Stanton, 1965).

Virally-induced epidermal papillomas have been reported in fish since the 16th century when "epithelioma papillosum" (also known as "carp pox") was a scourge of European carp farmers (Hofer, 1904). Such papillomas coalesce as they spread over the surface of carp as white plaques, and develop focal exophytic masses (Wildgoose, 1992). These papillomas are caused by Herpesvirus cyprini (also cyprinid herpesvirus 1, CHV) (Sano et al, 1991), regress in warm summers or when held above $20^{\circ} \mathrm{C}$ (Sano et al, 1993b), and persist below $15^{\circ} \mathrm{C}$ (Sano et al, 1993a). Viruses have also been associated with papillary epidermal plaques in other fish species (Wolf, 1988), such as walleye, in which a retroviral etiology is suspected (LaPierre et al, 1998).

A chemical etiology is suspected for papillomas in a number of fish species that live in polluted environments. These papillomas are typically exophytic rather than plaque-like (Baumann et al, 1996; Grizzle et al, 1988; Russell and Kotin, 1957). Evidence of chemical etiology of epidermal papillomas has been found in brown bullhead (Ameiurus nebulosus) (Black et al, 1985; Black, 1983a, 1983b; Brown et al, 1973; Folmar et al, 1995; Lucke and Schlumberger, 1941; Obert, 1997; Poulet and Spitsbergen, 1996; Poulet et al, 1993, 1994), channel catfish (Ictalurus punctatus) (Chen et al, 1996), and medaka (Oryzias latipes) (Hyodo-Taguchi and Matsudaira, 1987). Thus, papillomas in some fish have an epizootiologic and experimental basis for a chemical etiology, but have all occurred at frequencies much lower than that seen here.

Other tumors found in our ENU-treated zebrafish included a $1.5 \times 1 \times 0.9 \mathrm{~mm}$ malignant peripheral nerve sheath tumor in the distal tail of Fish $M$. A satellite nodule $(0.25 \times 0.25 \times 0.2 \mathrm{~mm})$ occurred 0.5 $\mathrm{mm}$ proximal to the main tumor. The histologic diagnosis is supported by features including wavy to plump spindle cells formed whorls, loose myxoid
(Antoni B), and more cellular (Antoni A) areas, nuclear palisades, rare Verocay bodies, focal large dark atypical spindle-shaped nuclei, infiltrative border, and mitoses (two per ten 400x fields; not shown) (Enzinger and Weiss, 1995; Hruban et al, 1990). Peripheral nerve sheath tumors have also been induced by ENU in the rat (Kindler-Rohrborn et al, 1999; Koestner et al, 1971; Nikitin et al, 1991; Perantoni et al, 1987). Two cavernous hemangiomas were also found in the mutagenized zebrafish. One was a $1 \times 1 \times 1 \mathrm{~mm}$ subcutaneous lesion in the head of Fish $\mathrm{M}$, and the other was a $5 \times$ $3 \times 3 \mathrm{~mm}$ lesion which completely replaced the soft tissues of the proximal tail of Fish V (not shown). These mesenchymal tumors were too few to firmly establish a relationship to the ENU treatment.

In summary, we report that ENU induced epidermal papillomas in all adult male zebrafish treated in a widely-used mutagenesis protocol. The high tumor incidence, combined with the strength of zebrafish as a genetic model system, establish the potential of the zebrafish as a model for the study of skin neoplasia.

\section{Materials and Methods}

\section{Mutagenesis}

Germ line mutations were induced in adult male zebrafish with $\mathrm{N}$-ethyl-N-nitrosourea (ethylnitrosourea, ENU; Sigma, St. Louis, Missouri) as described (Mullins et al, 1994). Wildtype zebrafish males were obtained from North American wholesalers, and a subset was chosen for mutagenesis based on a high fertility rate in pairwise matings. A total of 30 zebrafish males were treated at 7 to 9 months of age with either $0.0 \mathrm{~mm}$ ENU (6 control males, designated A to E), $2.5 \mathrm{~mm}$ ENU (12 males, designated $\mathrm{F}$ to $\mathrm{M}$ ), or $3.0 \mathrm{~mm}$ ENU (12 males, designated $\mathrm{N}$ to $\mathrm{W}$ ). Treatment consisted of 1-hour immersions at room temperature $\left(22^{\circ} \mathrm{C}\right.$ to $\left.23^{\circ} \mathrm{C}\right)$ every 72 hours for a total of three treatments. The ENU solution was freshly prepared within 1 hour of each treatment by a combination of stirring and crushing of powder aggregates. ENU solutions were inactivated by bringing them to $10 \mathrm{~mm} \mathrm{NaOH}$; containers were decontaminated in $250 \mathrm{~mm} \mathrm{NaOH} \mathrm{10 \%} \mathrm{sodium} \mathrm{thio-}$ sulfate overnight; and surfaces with any potential for aerosol contamination were covered and sprayed with $10 \mathrm{~mm} \mathrm{NaOH}$ after the mutagenesis. The control group was treated with buffer only $(0.03 \%$ Instant Ocean, Aquarium Systems, Mentor, Ohio; in $10 \mathrm{~mm}$ sodium phosphate, $\mathrm{pH}$ 6.7). All 30 fish survived this mutagenesis regimen well, although the $3.0 \mathrm{~mm}$ group exhibited signs of physiologic stress, such as huddling and poor feeding, compared with the other two groups. One of the control males and two of the $2.5 \mathrm{~mm}$ males died before our final inspection for tumors.

\section{Fish Care}

The fish were raised in a recirculating system (water turnover approximately 4 times/hour/tank) containing dechlorinated tap water mixed approximately 50:50 with reverse osmosis filtered water to a hardness of 68 to 85 
parts per million. Approximately $10 \%$ of the water was replaced daily. Treated and untreated fish had identical diets: once per day of 2-day-old brine shrimp (Argent, Redmond, Washington; Gold grade), and once per day of a coarsely ground mixture of equal parts by volume of Wardley Staple flake food (Wardley, Secaucus, New Jersey), 450 grade floating Trout Pellets (Rangen, Buhl, Idaho), Trout and Salmon Starter (Rangen), freeze-dried krill (Argent), and freeze-dried tubifex worms (Wardley). Fish were euthenized with tricaine methane sulphonate, as described (Westerfield, 1995).

\section{Gross and Microscopic Pathology}

After several months of breeding, these fish were kept in isolation for 10 to 12 months and scored for tumors, at 17 to 21 months of age. After euthanasia, whole fish were fixed in 10\% neutral buffered formalin for at least 1 day. Fish $\mathrm{H}, \mathrm{J}, \mathrm{M}, \mathrm{S}, \mathrm{U}$, and $\mathrm{V}$ were decalcified for 24 hours in $22.5 \%$ formic acid $300 \mathrm{~mm}$ sodium citrate, and the remaining fish were decalcified for 1 hour in Cal-EX (1.35 N HCl, 0.003 м Sodium EDTA, Fisher Scientific, Pittsburgh, Pennsylvania). Decalcified fish were returned to formalin in a tissue processing cassette, dehydrated, and impregnated with paraffin, and stained with hematoxylin and eosin according to standard protocols (Luna, 1968).

\section{Photography}

Gross photography was done using a Nikon F2 camera (Tokyo, Japan) with a Nikkor 55 mm f3.5 micro lens and a Honeywell (Morristown, New Jersey) slave Strobonar 200CA flash. Low-power photomicroscopy was done on a Leica M10 with a MPS60 camera, and higher power photos made on a Zeiss Axioscope with an MC 100 spot camera, and a variety of objectives. Slides were scanned using a Polaroid SprintScan 35 Plus scanner (Cambridge, Massachusetts) and adjustments made using Adobe Photoshop (San Jose, California).

\section{Acknowledgements}

We are grateful to Xiaohong Wang and Lynn Budgeon for their histotechnology work, and Manzoor Mohideen for his comments on the manuscript.

\section{References}

Baumann PC, Smith IR, and Metcalfe CD (1996). Linkages between chemical contaminants and tumors in benthic Great Lakes fish. J Great Lakes Res 22:131-152.

Berenblum I (1954). Carcinogenesis and tumor pathogenesis. Adv Cancer Res 2:129-175.

Berenblum I and Shubik P (1949). The persistence of latent tumor cells induced in the mouse's skin by a single application of 9:10-dimethyl-1,2-benzanthracene. Br J Cancer 3:384-386.

Black J, Fox H, Black P, and Bock F (1985). Carcinogenic effects of river sediment extracts in fish and mice. In: Jolley $\mathrm{RL}$, editor. Water chlorination: Chemistry, environmental impact and health effects. Chelsea, Michigan: Lewis Publishers, 415-427.
Black JJ (1983a). Epidermal hyperplasia and neoplasia in brown bullheads (Ictalurus nebulosus) in response to repeated applications of a PAH containing extract of polluted river sediment. In: Cooke M and Dennis AJ, editors. Polynuclear Aromatic hydrocarbons: Formation, metabolism, and measurement. Columbus, Ohio: Battelle Press, 99-111.

Black JJ (1983b). Field and laboratory studies of environmental carcinogenesis in Niagara River fish. J Great Lakes Res 9:326-334.

Bogovski P (1994). Tumours of the skin. In: Turusov VS and Mohr $\mathrm{U}$, editors. Tumours of the mouse. Lyon, France: International Agency for Research on Cancer, 1-45.

Bolontrade MF, Stern MC, Binder RL, Zenklusen JC, Gimenez-Conti IB, and Conti CJ (1998). Angiogenesis is an early event in the development of chemically induced skin tumors. Carcinogenesis 19:2107-2113.

Boutwell RK (1964). Some biological aspects of skin carcinogenesis. Prog Exp Tumor Res 4:207-250.

Brown ER, Hazdra JJ, Keith L, Greenspan I, Kwapinski JB, and Beamer $P$ (1973). Frequency of fish tumors found in a polluted watershed as compared to nonpolluted Canadian waters. Cancer Res 33:189-198.

Chen HC, Pan IJ, Tu WJ, Lin WH, Hong CC, and Brittelli MR (1996). Neoplastic response in Japanese medaka and channel catfish exposed to N-methyl- $\mathrm{N}^{\prime}-$ nitro- $\mathrm{N}$ nitrosoguanidine. Toxicol Pathol 24:696-706.

DiGiovanni J (1992). Multistage carcinogenesis in mouse skin. Pharmacol Ther 54:63-128.

Driever W and Fishman MC (1996). The zebrafish: Heritable disorders in transparent embryos. J Clin Invest 97:1788-1794.

Eisen JS (1996). Zebrafish make a big splash. Cell 87:969977.

Enzinger FM and Weiss SW (1995). Benign tumors and tumorlike conditions of blood vessels. Benign tumors of peripheral nerves. Malignant tumors of peripheral nerves. In: Enzinger FM and Weiss SW, editors. Soft tissue tumors. St. Louis: Mosby, 586-588, 829-842, 902.

Folmar LC, Harshbarger J, Baumann PC, Gardner G, and Bonomelli S (1995). Pathological and serum chemistry profiles of brown bullheads (Ameiurus nebulosus) from the Black River and Old Woman Creek, Ohio. Bull Environ Contam Toxicol 54:50-59.

Friedewald WF and Rous P (1944). The initiating and promoting elements in tumor production: An analysis of the effects of tar, benzpyrene, and methylcholanthrene on rabbit skin. $J$ Exp Med 8:101-126.

Grizzle JM, Horowitz SA, and Strength DR (1988). Caged fish as monitors of pollution: Effects of chlorinated effluent from a wastewater treatment plant. Water Resour Bull 24:951-959.

Hendricks JD (1996). Development of the zebra Danio model: Carcinogenesis and gene transfer studies. Springfield, Virginia: ADA32886, National Technical Information Service, US Department of Commerce.

Hofer B (1904). Pockenkrankheit des karpfens, chapter 14. Handbuch der Fishkrankheiten. Munich, Germany, Verlag der Allg Fischerei-Zeitung, 61-71.

Hruban RH, Shiu MH, Senie RT, and Woodruff JM (1990). Malignant peripheral nerve sheath tumors of the buttock and lower extremity: A study of 43 cases. Cancer 66:1253-1265. 
Hyodo-Taguchi $Y$ and Matsudaira $H$ (1987). Higher susceptibility to N-methyl-N'-nitro-N-nitrosoguanidine-induced tumorigenesis in an interstrain hybrid of the fish, Oryzias latipes (medaka). Jpn J Cancer Res 78:487-493.

Kindler-Rohrborn A, Kolsch BU, Fischer C, Held S, and Rajewsky MF (1999). Ethylnitrosourea-induced development of malignant schwannomas in the rat: Two distinct loci on chromosome of 10 involved in tumor susceptibility and oncogenesis. Cancer Res 59:1109-1114.

Kobayashi T, Urakami S, Hirayama Y, Yamamoto T, Nishizawa M, Takahara T, Kubo Y, and Hino O (1997). Intragenic Tsc2 somatic mutations as Knudson's second hit in spontaneous and chemically induced renal carcinomas in the Eker rat model [see comments]. Jpn J Cancer Res 88:254-261.

Koestner A, Swenberg JA, and Wechsler W (1971). Transplacental production with ethylnitrosourea of neoplasms of the nervous system in Sprague-Dawley rats. Am J Pathol 63:37-56.

LaPierre LA, Holzschu DL, Wooster GA, Bowser PR, and Casey JW (1998). Two closely related but distinct retroviruses are associated with walleye discrete epidermal hyperplasia. J Virol 72:3484-3490.

Lijinsky W, Pegg AE, Anver MR, and Moschel RC (1994). Effects of inhibition of O6-alkylguanine-DNA alkyltransferase in rats on carcinogenesis by methylnitrosourea and ethylnitrosourea. Jpn J Cancer Res 85:226-230.

Lucke B and Schlumberger HG (1941). Transplantable epitheliomas of the lip and mouth of catfish, I Pathology: Transplantation to anterior chamber of eye and into cornea. $J$ Exp Med 74:397-408 and Figure Plates 18-22.

Luna LG (1968). Manual of histologic staining methods of the Armed Forces Institute of Pathology, 3rd Edition. New York: McGraw-Hill.

Mullins MC, Hammerschmidt M, Haffter $P$, and NussleinVolhard C (1994). Large-scale mutagenesis in the zebrafish: In search of genes controlling development in a vertebrate. Curr Biol 4:189-202.

Nikitin A, Ballering LA, Lyons J, and Rajewsky MF (1991). Early mutation of the neu (erbB-2) gene during ethylnitrosourea-induced oncogenesis in the rat Schwann cell lineage. Proc Natl Acad Sci USA 88:9939-9943.

Obert EC (1997). Presque Isle Bay brown bullhead tumor study: Conducted from March 29, 1992 to October 7, 1993. Pennsylvania Department of Environmental Protection, Bureau of Water Management, Northwest Region.

O'Connell JF, Nesnow S, and Slaga TJ (1987). Initiation, promotion and complete carcinogenesis by $\mathrm{N}$-methyl- $\mathrm{N}^{\prime}-$ nitro-N-nitrosoguanidine or ethylnitrosourea in the Sencar mouse skin tumorigenesis model. Cancer Lett 37:301-310.

Peckham JC and Heider K (1999). Skin and subcutis. In: Maronpot RR, Boorman GA, and Gaul BW, editors. Pathology of the mouse. Vienna, Illinois: Cache River Press, 580-582.

Perantoni AO, Rice JM, Reed CD, Watatani M, and Wenk ML (1987). Activated neu oncogene sequences in primary tumors of the peripheral nervous system induced in rats by transplacental exposure to ethylnitrosourea. Proc Natl Acad Sci USA 84:6317-6321.

Poulet FM, Casey JW, and Spitsbergen JM (1993). Studies of the transmissibility and etiology of orocutaneous tumors of brown bullheads (Ictalurus nebulosus). Dis Aquat Org 16:97-104.
Poulet FM, and Spitsbergen JM (1996). Ultrastructural study of spontaneous orocutaneous papillomas of brown bullheads (Ictalurus nebulosus). Dis Aquat Org 24:93-98.

Poulet FM, Wolfe MJ, and Spitsbergen JM (1994). Naturally occurring orocutaneous papillomas and carcinomas of brown bullheads (Ictalurus nebulosus) in New York State. Vet Pathol 31:8-18.

Robins CR, Bailey RM, Bond CE, Brooker JR, Lacher EA, and Lea RN (1991). Common and scientific names of fishes from the United States and Canada, Special Publication, vol 20. Bethesda, Maryland: American Fisheries Society.

Russell FE and Kotin P (1957). Squamous papilloma in the white croaker. J Natl Cancer Inst 18:847-861.

Sano N, Moriwake M, Hondo R, and Sano T (1993a). Herpesvirus cyprini: A search for viral genome in infected fish by in situ hybridization. J Fish Dis 16:495-499.

Sano N, Moriwake M, and Sano T (1993b). Herpesvirus cyprini: Thermal effects on pathogenicity and oncogenicity. Fish Pathol 28:171-175.

Sano T, Morita N, Shima N, and Akimoto M (1991). Herpesvirus cyprini: Lethality and oncogenicity. J Fish Dis 14:533-543.

Schartl A, Pagany M, Engler M, and Schartl M (1997). Analysis of genetic factors and molecular mechanisms in the development of hereditary and carcinogen-induced tumors of Xiphophorus. Recent Results Cancer Res 143:225-235.

Shibuya T and Morimoto K (1993). A review of the genotoxicity of 1-ethyl-1-nitrosourea. Mutat Res 297:3-38.

Solnica-Krezel L, Schier AF, and Driever W (1994). Efficient recovery of ENU-induced mutations from the zebrafish germline. Genetics 136:1401-1420.

Stanton MF (1965). Diethylnitrosamine-induced hepatic degeneration and neoplasia in the aquarium fish, Brachydanio rerio. J Natl Cancer Inst 34:117-130.

Streisinger G, Singer F, Walker C, Knauber D, and Dower N (1986). Segregation analyses and gene-centromere distances in zebrafish. Genetics 112:311-319.

Tong HH, Park JH, Brady T, Weghorst CM, and D'Ambrosio SM (1997). Molecular characterization of mutations in the hprt gene of normal human skin keratinocytes treated with $\mathrm{N}$-ethyl-N-nitrosourea: Influence of O6-alkylguanine alkyltransferase. Environ Mol Mutagen 29:168-179.

Tsai H-W (1996). Evolution of zebrafish (Danio rerio) as a model for carcinogenesis. Corvalis, Oregon: Oregon State University, PhD Thesis.

Westerfield M (1995). The zebrafish book: Guide for the laboratory use of zebrafish (Danio rerio), 3rd ed, Eugene, Oregon: University of Oregon Press.

Wildgoose WH (1992). Papilloma and squamous cell carcinoma in koi carp (Cyprinus carpio). Vet Rec 130:153-157.

Wolf K (1988). Fish viruses and fish viral diseases. Ithaca and London: Comstock Publishing Associates, Cornell University Press, 476.

Yuspa SH (1998). The pathogenesis of squamous cell cancer: Lessons learned from studies of skin carcinogenesis. J Dermatol Sci 17:1-7.

Zon LI (1999). Zebrafish: A new model for human disease (Comment). Genome Res 9:99-100. 